\title{
An introduction to didactic classroom studies
}

\section{Christina Osbeck, Åke Ingerman \& Silwa Claesson}

\section{Didaktik - an ambiguous concept}

Didaktik is the term used in the Scandinavian countries and Germany for a special area of educational science, but it tends not to translate well into English, where didactic has partly negative connotations related to conveying and sententious processes (Gundem 2011). One solution has been simply not to translate the term-Hudson (2007), for example, uses its German form, Didaktik - but given that the Continental European and Scandinavian meaning of didactics is now standard in the anglophone educational sciences (Riquarts \& Hopmann 1995; Klette 2007) and its relation to 'curriculum studies' has been discussed (Gundem \& Hopmann 1998), we have chosen to translate didaktik as didactics, being the best of the necessary elisions when writing in English.

Didactics is a field of research that encompasses the collective knowledge of all teachers at the point where academic knowledge and practice intersects (Fensham 2004; Gundem 2011). It is understood as both the science of the teaching profession and the professional knowledge that teachers possess (Ingerman \& Wickman 2015; Kindenberg \& Wickman 2018; Seel 1999), with the latter frequently referred to as the art of teaching (for example, Bronäs \& Runebou 2010). This double meaning can be confusing for the uninitiated, but it reveals just how closely related theory and practice in didactics are, or, as Klafki has it, how little separated these two realities are when 
it comes to educational processes (Gundem 2011). Our aim here is thus first and foremost to contribute to didactics as an empirical science-articulating classroom studies as a potential research direction for didactic studies, and suggesting directions that will put such studies at the cutting edge. However, since the findings of didactic classroom studies are important for the development of practice this means that ours is also a contribution to classroom practice-our empirical studies and their findings have 'didactical consequences' for teachers, as we have chosen to phrase it here.

Although didactics is today a distinct field of educational science in Sweden, and is one with deep roots in all the Scandinavian countries and Germany, didactics as a concept was noticeable by its absence in the period between the Second World War and the 1980s (Werler et al. 2016). Its return to favour as a concept was linked to the educational reforms in teaching in the late eighties, when it became important to invoke the long tradition of didactics (for example, Kroksmark 1989). This tradition differs considerably in the retelling, but most accounts still begin with the Greek root of the term, and then trace it via Comenius and Herbart to Germany, where Bildung theory and critical theory took effect (Gundem 2011).

Not only does didactics draw on a variety of traditions and theories, but the general level of interest in it has varied. The classic distinction between general didactics and subject-matter didactics is usually the first to be noticed. Even though 'subject-matter didactics' is a well-established concept (Swedish ämnesdidaktik, Danish fagdidaktik, Norwegian fagdidaktikk), it can be thought tautological since content-centredness is implied by the word didactics. A less common but still crucial differentiation in didactics centres on the institutional setting in question. This usually corresponds to the age of the learners. Hence preschool didactics is held to be distinct from primary school didactics, lower secondary school didactics from upper secondary and university didactics, and so on. This is sometimes called 'special didactics' (Gundem 2011). In the didactic classroom studies presented in this volume, we consider a range of subject matter. The content, while shifting, is evident in all eight studies, although in a couple of studies-Hipkiss's and Lilja and Claesson's - the primary interest is the generic processes more than the specific content. This section of 
the book thus goes under the heading of 'The framing of teaching in the classroom, but the processes could equally be understood as disciplining processes, that have been understood, in addition to teaching and guiding processes, as a central focus in general didactics having both a relational and an organisational dimension (Oettingen 2016), as the two essays exemplify. The various didactical subareas make it possible to specialise, which while productive has also hampered the synergies that could have been beneficial for knowledge development in the field (Künzli 2000), as for example in the research approaches that are our focus here. Our empirical studies also show that the appearance of a distinction between studies in general didactics and subject-matter didactics varies according to the age of the pupils or students and the subject taught. The character of a didactical tradition is relevant to the research being produced, as is discussed here in Osbeck and Ingerman's essay on a potential research direction for didactic classroom studies, which looks at science and religious education.

\section{Common characteristics of didactics}

Despite the fact that different sources are cited and different points are emphasised, there are some common characteristics to be found in didactics, which we would argue are fundamental and help didactics avoid the worst of its fragmentary tendencies (Hudson \& Meyer 2011). Some of these features have already been noted. Didactics is said to draw closely on practice, which is sometimes said to have become clearer as subject-matter didactics evolved. According to Gundem 'subject didactics in a way saved didactics. It brought didactics back to the content and classroom' $(2011,99)$. To stress practice is to stress complexity. The practice-focused character of didactics can be interpreted as visualising and embodying the full complexity of the teaching-studying-learning process (Hudson 2007). Didactic studies like the ones in this volume have an interest in understanding the complexities of classroom teaching and learning without reductio ad absurdum arguments, and instead stress the context in these processes.

Another common trait in didactics is its attention to the intentionality of the teaching and learning process, and in that sense its normativity. 
In a school setting, teaching is a specific 'restrained teaching' (Hopmann 2007). An interest in intentionality can take many forms. It can be a critique of its ideological character, as in critical didactics (Gundem 2011)_looking at the tensions between policy, the teachers' express ambitions, observed processes, and pupil experiences. It may identify differences between explicit and implicit processes, and in that sense reveal a 'hidden curriculum' (Jackson 1968). Teaching and learning processes in the classroom always include values, and, inevitably, negotiations about which values should count (Fenstermacher et. al. 2009). Intentionality in a school context also turns on the fact that successful schooling is not just the result of socialisation in general, but rather is brought about by planned processes that centre on 'powerful knowledge' (Fredricks et al. 2004; Young 2013). In the didactical Bildung tradition, the intentional aspect of teaching turns on pupil or student development in an overarching, long-term perspective. There are questions about how school-and especially its selected content-contributes to character development and individual responsibility (for example, Gundem 2011; Künzli 2000). Bildung didactics thus pays attention not only to the tensions between individual and societal ambitions for development in schools, but also to the risk that the intention with teaching and learning might be understood in a narrow, instrumental way (Klafki 1995; Hudson 2007). In the present volume, intentionality is one of several analytical perspectives, with which teaching and learning processes are interpreted and evaluated. In-depth studies of the extent to which current teaching processes can contribute to the development of wise, responsible, and independent individuals (Oettingen 2016) - teaching processes that could be related to Biesta's function of education as being subjectification, alongside qualification and socialisation (2009) - are something for another volume.

The most commonly noted characteristic is perhaps the didactical questions used for reflective planning processes and analyses of ongoing teaching: what is being taught and learnt, how is this effected, and why-with what purpose-is this carried out (for example, Ongstad 2006; Jank \& Meyer 1997). The importance of keeping the content and the working processes together is clear in such didactical 
questions. The perspective is often referred to as constitutive in a tradition that runs from Comenius to Pestalozzi, where it was originally expressed as an interest in finding a natural way of teaching and learning in accordance with the nature of the content (Riquarts \& Hopmann 1995). Didactics scholars are often sceptical about the benefit of general theories of teaching and learning (Kindenberg \& Wickman 2018), and instead favour the production of local theories; for example, articulated didactic models where the specific content is central (Wickman et al. 2018). Such didactic models have been developed to support teachers' analyses and educational choices (Duit et al. 2012; Ruthven et al. 2009), and provide a conceptual toolbox with which to tackle didactic questions. Mangling didactic models in practice (in analogy with Pickering 1993) allows for the development of the models and for knowledge interaction at the point where practice and research intersect, and as such is an important means of developing didactics. The didactic models can be understood as local theories in several ways. They can be embedded in a specific practice, or they can be local in the what and how of teaching and learning; they can also be localised in a particular subject didactics, as for example Robert's (2007) model of scientific literacy as comprising two visions (an insider and an outsider perspective).

Closely related to the didactical questions is the didactical triangle - the expression of didactical interest in the form of a triangle (for example, Hopmann 2007). The integrative ambition of didactics - the simultaneous interest in content, pupils, and teachers, and how these three components interrelate in the teaching and learning process-is plain here. The components are integrated so that one component cannot be highlighted at the expense of another without the loss of valuable information (Straesser 2007; Werler et al. 2012).

\section{Pursuing didactical research interests with classroom studies}

Our didactical research interest in this volume is classroom practice, while retaining its complexity and making its goals and intentionality visible. We have adopted a holistic, integrative perspective, which 
has been described elsewhere as the common and distinctive feature of the didactical tradition: 'What all these efforts have in common is the strong belief that we need an integrative approach, as intended by Herbart and Comenius, which can do justice to each corner of the didaktik triangle: the teacher, the content and, not least, the learner who has to come to terms with this ever more complicated world' (Riquarts \& Hopmann 1995, 8-9). The three corners of the didactical triangle-teacher, pupil, content-must be understood in an integrative perspective. However, the limitations of data, method, or focus often lead to an analytical separation of these components in didactic studies, with one component commonly featuring large while the other two are explicitly or implicitly relegated to the background. This limits complexity and can hamper how classroom practice is reflected in the studies. A didactical research interest that stresses the integrative focus is one that takes steps to keep intact the contextual wholeness in relation to the practice. Uljens thus defines didactics as 'the science of the teaching-studying-learning process' (2012, 43).

In this volume, we argue for the value of classroom studies as a way of gauging the ongoing process of teaching and learning in all their complexity. We would argue that didactic classroom studies are a self-contained and fruitful research direction, and thus exemplify the characteristics of such studies with eight empirical studies, and offer suggestions as to the international research context and how it might develop and thrive.

\section{The empirical studies}

The didactic classroom studies in this volume, in accordance with the opportunities offered by such studies, offer a range of contextual perspectives and findings in which teaching, learning, and content are kept together. Nevertheless, the particular emphasis varies from essay to essay. 


\section{The teacher in the classroom}

The essays that particularly focus on teachers and their work in the classroom show how different kinds of teaching strategy make different kinds of learning possible, as the objects of learning become visible to varying degrees in the classroom through the teacher's actions. Teachers' actions affect the pupils' activities, which in turn affect what teachers do. While the emphasis is on the teacher, the essays show that relationships are important in the teaching and learning processes and in the communication that is established between teachers and pupils. This is the theme of Osbeck's essay, which examines how communicative patterns in the classroom provide varying conditions for learning, and how communicative patterns are negotiated by teachers and pupils. Osbeck's concern is whether a teacher's actions enable certain speech genres to become hegemonic in the classroom-speech genres that to varying degrees can impact on the development of a subject-matter language. Kullberg and Skodras's essay shows how examples used by teachers, and the variation in their use of examples, elicit pupil understandings of various kinds. Different opportunities to identify patterns and achieve insights are offered.

\section{The student in the classroom}

Two of the essays concentrate on pupils' or students' work in small groups, and articulate the development and nature of their understandings. By focusing on the students' perspectives in classroom studies, in contrast to the opportunities provided by, say, interviews or questionnaires, one can be certain that the contextual processes, relationships, and communication are taken into account. In Ingerman and Booth's essay, work in small groups is analysed in relation to the role of the tutor, while Sofkova Hashemi's essay concentrates on pupils and their choices, how they handle tasks given to them by both teachers and fellow pupils, and how they construct tasks, taken to be a measure of the skills that the pupils have to mobilise. 
The study also shows how this relates to the tasks given to them and their communication with their peers. The findings touch on what it means when pupils show or do not show certain skills under these circumstances.

\section{The framing of teaching in the classroom}

Lilja and Claesson's essay pays particular attention to the relational conditions of classroom work, while Hipkiss's focuses on the physical circumstances. Both essays can be said to concentrate on the framing and conditions of classroom work, and are more general in character, as described above (Oettingen 2016). Hipkiss's contribution gives an insight into how relationships are conditioned by the possibilities of the physical milieu of the classroom. The ways a classroom is furnished has an impact on pupils' opportunities to practise subject-specific language, demonstrating that the line between general didactics and subject-matter didactics is not always easy to draw. Even though the relational and physical aspects matter, and in one way or another are visible in all classroom studies, these two essays show the importance of taking these conditions for teaching and learning as a subject of study in their own right. A closer look at current work in the classroom reveals how different types of teaching strategy can facilitate a variety of relational patterns, and thus give pupils the opportunity to expand their horizons of understanding. These two essays together point to how relational, physical context affects teaching and learning, and that makes change possible.

\section{Researching the classroom}

The remaining two empirical essays are both based on videorecorded data from classrooms, and concentrate on methodological issues - what kinds of knowledge are made possible by these studies and how different approaches reveal different things-while stressing the importance of combining overarching and in-depth analyses. In the contribution by Kilhamn et al., specific international comparisons are demonstrated to be a useful methodological tool with which to 
identify possible international differences and the contextualisation of teaching. The authors also discuss how video observations are a valuable method for developing work with teachers and how together their interpretations can enrich the teaching and learning process. Rocksén's essay shows that the patterns evident in many hours of recorded data can provide a solid base for the selection of specific episodes for in-depth study. The patterns in how a teacher performs a specific action are identifiable only by studying a certain number of lessons, as it is only then one can distinguish between the rule and the exception. Sequential observations are fundamental when studying progression in communication patterns and language, especially if the ambition is to identify whether patterns and perspectives established in previous lessons continue to be drawn upon in current teaching.

\section{The wider view on didactic classroom studies}

The empirical essays illustrate the complexities of our knowledge about classroom teaching and learning. In Osbeck and Ingerman's essay on potential research directions, the eight are categorised according to their aim, theoretical framework, empirical design, didactical research tradition, knowledge claims, and implications, and considered for their future potential in didactic classroom studies, while also singling out the factors that may carry this research direction forward. Finally, Klette concludes with an international perspective on didactic classroom studies, with brief comments on each of the empirical essays and a discussion of their contribution as a whole to the international field.

\section{The Swedish context}

In didactic classroom studies the specific context is of large importance. Most of the classrooms are embedded in a Swedish school system which may not be familiar to the reader, so a brief introduction is in order. Since 1842 , Sweden has had compulsory education for all 
children, and today most children go to preschool, all children have nine years of obligatory schooling, and most young people continue for another three years at an upper-secondary school. The Swedish school system is broadly similar to the other Nordic countries, especially when it comes to its religious and political background (historically, Lutheranism and social democracy have dominated). In the 1960 s there was school reform similar to many anglophone countries, and the school system changed from one with several different tracks to an elementary school which all pupils attended for the full nine years. However, in the 1990 s so-called free schools (fristående skolor) were permitted, and today there is a debate as to whether this has opened up for a new kind of segregation. There are also international influences at work, for example from the OECD, which affect how teaching and learning are regarded. The notion of accountability has also recently been stressed in the Scandinavian countries (Skarre Aasebo et al. 2017). These wider processes affect teaching and learning in individual classrooms, and are thus evident in our results even though they are not the specific research focus of these studies.

With this introduction, we as editors invite you to enjoy each individual study and reflect on the contribution of classroom studies as a potential research direction in the field of didactics.

\section{References}

Biesta, G. (2009), 'Good education in an age of measurement: On the need to reconnect with the question of purpose in education', Educational Assessment, Evaluation \& Accountability, 21/1, 33-46.

Bronäs, A. \& N. Runebou (2010), Ämnesdidaktik: En undervisningskonst (Stockholm: Norstedt).

Duit, R., H. Gropengieber, U. Kattmann, M. Komorek \& I. Parchmann (2012), 'The model of educational reconstruction: A framework for improving teaching and learning science', in D. Jorde \& J. Dillon (eds.), Science education research and practice in Europe (Rotterdam: Sense).

Fensham, P. J. (2004), Defining identity: The evolution of science education as a field of research (Dordrecht: Kluwer Academic).

Fenstermacher, G. D., R. D. Osguthorpe \& M. N. Sanger (2009), 'Teaching Morally and Teaching Morality', Teacher Education Quarterly, 36/3, 7-19. 
Fredricks, J. A., P. C. Blumenfeld \& A. H. Paris (2004), 'School engagement: Potential of the concept, state of the evidence', Review of Educational Research, $74 / 1,59-109$.

Gundem, B. B. (2011), Europeisk didaktikk: Tenkning og viten (Oslo: Universitetsforlaget).

Hopmann, S. (2007), 'Restrained teaching: The common core of didaktik', European Educational Research Journal, 6/2, 109.

Hudson, B. (2007), 'Comparing Different Traditions of Teaching and Learning: What can we learn about teaching and learning?' European Educational Research Journal, 6/2, 135-46.

Ingerman, Å. \& P. O. Wickman (2015), 'Towards a teachers' professional discipline: Shared responsibility for didactic models in research and practice, in P. Burnard, B. M. Apelgren \& N. Cabaroglu (eds.), Transformative teacher research: theory and practice for the C21st (Rotterdam: Sense).

Jackson, P. W. (1968), Life in the classroom (New York: Holt, Rinehart \& Winston). Jank, W. \& H. Meyer (1997), 'Nyttan av kunskaper i didaktisk teori', in M. Uljens (ed.), Didaktik: Teori, reflektion och praktik (Lund: Studentlitteratur).

Kindenberg, B. \& P. O. Wickman (2018), 'Dags för didaktiken att bli egen vetenskap', Pedagogiska Magasinet, 2, 14-17.

Klafki, W. (1995), 'Didactic analysis as the core of preparation of instruction (Didaktische Analyse als Kern der Unterrichtsvorbereitung)', Journal of Curriculum Studies, 27/1, 13-30.

Klette, K. (2007), 'Trends in Research on Teaching and Learning in Schools: Didactics meets classroom studies', European Educational Research Journal, $6 / 2,147-60$.

Kroksmark, T. (1989), Didaktiska strövtåg: Didaktiska idéer från Comenius till fenomenografisk didaktik (Gothenburg: Daidalos).

Künzli, R. (2000), 'German Didaktik: Models of re-presentation, of intercourse, and of experience', in I. Westbury, S. Hopmann \& K. Riquarts (eds.), Teaching as a reflective practice: The German Didaktik tradition (Mahwah, NJ: Lawrence Erlbaum).

Ongstad, S. (2006), 'Fag i endring: Om didaktisering av kunskap', in id. (ed.), Fag og fagdidaktikk i loererutdanning: Kunnskap i grenseland (Oslo: Universitetsforlaget).

Oettingen, A. von (2016), Almen dannelse: Dannelsesstandarder ogfag (Copenhagen: Hans Reitzels).

Pickering, A. (1993). 'The mangle of practice: Agency and emergence in the sociology of science', American journal of sociology, 99/3, 559-589.

Riquarts, K. \& S. Hopmann (1995), 'Starting a dialogue: Issues in a beginning conversation between Didaktik and the curriculum traditions', Journal of Curriculum Studies, 27/1, 3-12. 
Roberts, D. A. (2007), 'Scientific literacy/science literacy', in S. K. Abell \& N. G. Lederman (eds.), Handbook of research on science education (Mahwah, NJ: Lawrence Erlbaum).

Ruthven, K., C. Laborde, J. Leach \& A. Tiberghien (2009), 'Design tools in didactical research: Instrumenting the epistemological and cognitive aspects of the design of teaching sequences', Educational Researcher, 38, 329-42.

Seel, H. (1999), 'Didaktik as the professional science of teachers', TNTEE Publications, 2, 85-93.

Skarre Aasebo, T., J. Midsundstad \& I. Willbergh (2017), 'Teaching in the age of accountability: restrained by school culture?' Journal of Curriculum Studies, $49 / 3$.

Straesser, R. (2007), 'Didactics of mathematics: More than mathematics and school', ZDM 39/1, 165-71. doi: 10.1007/s11858-006-0016-x

Uljens, M. (2004), School didactics and learning: A school didactic model framing an analysis of pedagogical implications of learning theory. (Hove: Taylor \& Francis).

Werler, T., D. L. Cameron \& N. Birkeland (eds.) (2012), When Education Meets the Care Paradigm (Münster: Waxmann).

- - S. Claesson \& O. Strandler (2016), 'Sweden', in H. Döbert, W. Hörner, B. von Kopp \& L. Reuter (eds.), Die Bildungssysteme Europas (Baltmannsweiler: Schneider Verlag Hohengehren).

Wickman, P. O., K. Hamza \& I. Lundegård (2018), 'Didactics and didactic models in science education', Nordic Studies in Science Education, 14/3, 239-49. Young, M. (2013), 'Overcoming the crisis in curriculum theory: A knowledgebased approach', Journal of Curriculum Studies, 45/2, 101-118. 